\title{
Notes de relecture
}

Notes From a New Reading

Notas de relectura

\section{Claude Grignon}

\section{(C) OpenEdition}

Journals

Édition électronique

URL : http://journals.openedition.org/bssg/126

DOI : $10.4000 /$ bssg. 126

ISSN : 2490-9424

Éditeur

Presses universitaires de Vincennes

Référence électronique

Claude Grignon, « Notes de relecture », Biens Symboliques / Symbolic Goods [En ligne], 1 | 2017, mis en ligne le 15 octobre 2017, consulté le 04 mars 2021. URL : http://journals.openedition.org/bssg/126 ; DOI : https://doi.org/10.4000/bssg.126 

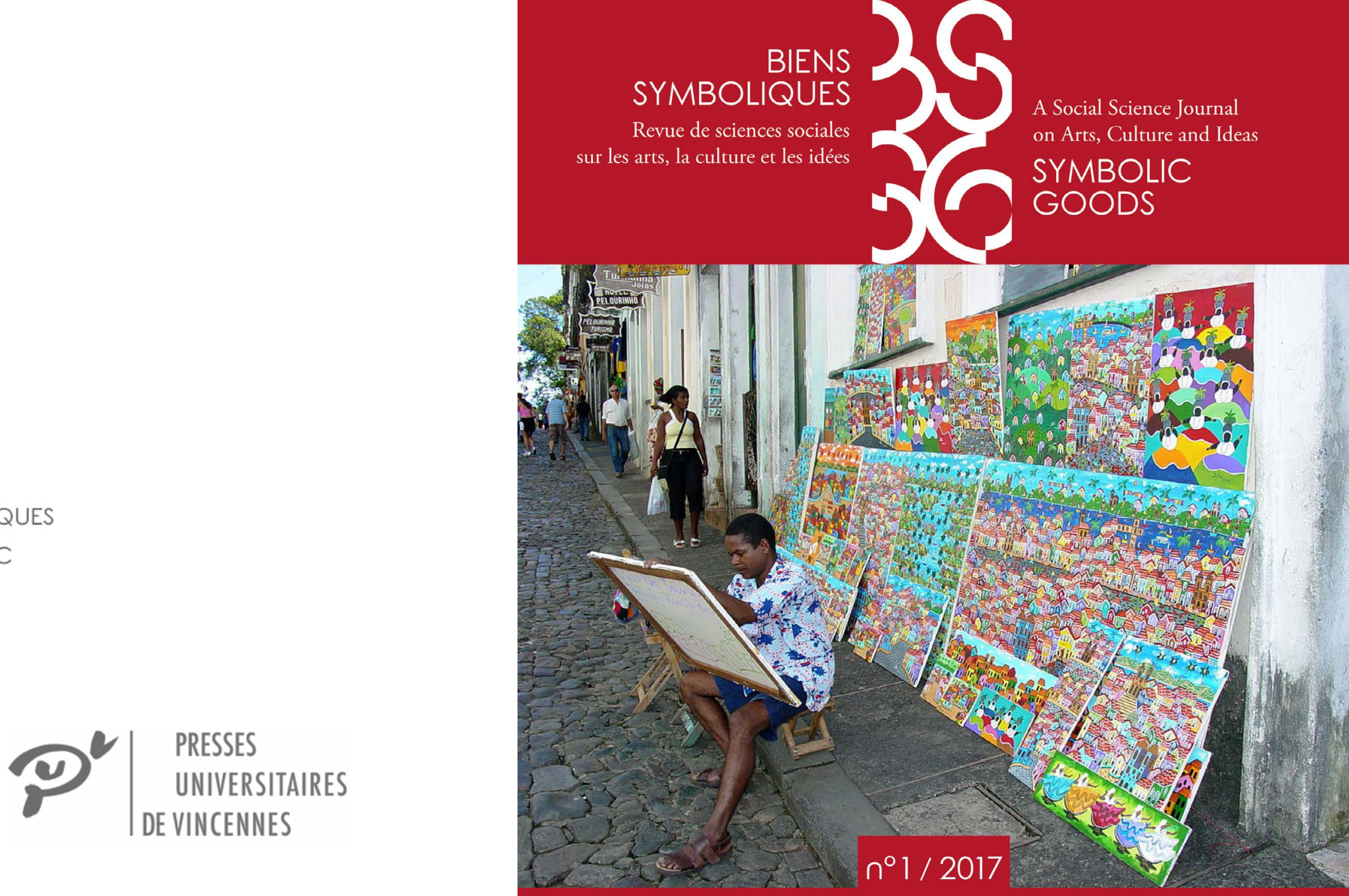

\section{Artistes ordinaires \\ Ordinary Artists}




\title{
Notes de relecture Notes from a New Reading
}

\author{
Claude Grignon \\ traduction | translation \\ Jasmin Smith \\ corrigée par | revised by \\ Delaina Haslam
}

Issu d'un séminaire donné à l'EHESS en 1982, publié sous différentes versions et pour la première fois sous la forme d'un livre en 1989 (Grignon \& Passeron 1983 ; 1985 ; 2015),

Le Savant et le Populaire n'a rien perdu de son actualité. Les questions de sociologie dont nous traitons, Jean-Claude Passeron et moi, sont devenues des « questions sociétales », rebattues dans les médias ; le terme de «populisme » est de plus en plus populaire. Les relations entre dominants et dominés, entre les « élites » et le Peuple, « vrais gens » ou « citoyens lambda », sont de plus en plus l'objet de débats d'opinion. II en va de même en ce qui concerne « l'accueil » des immigrés porteurs de cultures étrangères : faut-il les assimiler culturellement pour les intégrer socialement, ou conserver leur identité (i.e. leur altérité) culturelle au risque de les isoler et de les exclure ?

Cette actualité médiatique nous concerne, mais ce n'est pas celle qui nous intéresse ; c'est en sociologie et en littérature, et non en politique que nous traitons du populisme. Elle peut ajouter aux obstacles que rencontre et aux risques que court le sociologue qui se hasarde à étudier les classes et les cultures populaires et dominées. Les enjeux
Inspired by a seminar given at EHESS in 1982, published in different versions and for the first time in the form of a book in 1989 (Grignon \& Passeron, 1983, 1985, 2015), Le Savant et le Populaire has not lost any of its relevance. The sociological questions that Jean-Claude Passeron and I wrote about have become "societal questions" that are constantly rehashed in the media; the term "populism" is increasingly popular. The relations between the dominant and the dominated classes, between the "elites" and the People, "real people" or "the man in the street," figure more and more prominently at the centre of opinion debates. The same can be said of that which concerns the "acceptance" of immigrants from foreign cultures: should they assimilate into our culture to be integrated into society, or preserve their cultural identity (i.e., their otherness) at the risk of becoming isolated and excluded?

We are concerned by those topics, but they are not what we are most interested in: we deal with populism in sociology and literature, not in politics. These topics can add obstacles and risks for the sociologist who ventures to study popular and dominated classes and cultures. The political stakes that this study involves run the risk of waking the intellectual "who we 
politiques dont cette étude est l'objet risquent en effet de réveiller l'intellectuel « qui comme on sait sommeille en tout sociologue » (Grignon \& Passeron 2015 : 117) et de fausser nos interprétations, voire nos constats, en les soumettant à des parti pris et à des préjugés idéologiques. Pour nous autres sociologues, l'actualité du Savant et le Populaire tient à ce que les questions de sociologie dont il traite n'ont pas cessé de se poser. Sur des questions éminemment sociales, nous nous sommes efforcés de prendre le point de vue le plus sociologique possible, en inventoriant et en formulant les questions qu'elles posent à la sociologie. Le Savant et le Populaire est un exercice d'épistémologie, une application de la vigilance bachelardienne aux instruments et aux opérations, empiriques et mentales, que la sociologie des cultures populaires met en œuvre. Les réflexions théoriques que nous poursuivons, les concepts que nous élaborons sont issus de l'inventaire critique de l'outillage dont nous disposons ; on s'est efforcé de mettre au jour ses présupposés et ses orientations implicites, ce qu'il permet et ce qu'il empêche de voir et de savoir, ses limites, ses pièges et ses dérives.

«Société » et « culture » : ces concepts, qui sont au fondement et au centre de nos analyses, sont de ces mots usuels, à la fois savants et ordinaires, qui disent « quelque chose à tout le monde » parce que nul ne sait au juste ce qu'ils veulent dire. Disons pour commencer que la société est ce qui intéresse le sociologue, et que la culture est ce qui intéresse l'ethnologue; en l'espèce c'est bien le point de vue qui fait l'objet. Dans $L e$ Savant et le Populaire, nous avons décidé de "circonscrire la question aux formes de domination qui s'exercent au sein d'une même société »(18), en l'occurrence la société know sleeps within every sociologist" (Grignon \& Passeron 2015: 117), and of skewing our interpretations, or even our observations, by subjecting them to ideological biases and prejudices. For we sociologists, the relevance of Le Savant et le Populaire is due to the permanence of the sociological questions it addressed, which have never stopped being asked. Regarding eminently social questions, we strove to take the most sociological point of view possible by reviewing and formulating the questions that they pose to sociology. Le Savant et le Populaire is an epistemological exercise, an application of the Bachelardian vigilance to the empirical and mental operations and instruments involved in the sociology of working-class cultures. The theoretical reflections that we pursue, the concepts that we elaborate on, come from a critical inventory of the tools at our disposal; we endeavoured to find out their presuppositions and implicit orientations; what they allow and what they prevent from being seen and known, their limits, their traps, and their drifts.

"Society" and "culture:" these concepts, which are the basis for and at the centre of our analyses, are examples of the kinds of words which are both ordinary and scholarly, which mean "something to everyone" because no one knows exactly what they mean. Let us say that society is what the sociologist studies and culture is what is studied by ethnologists; in this case, it truly is the point of view that creates the object. In Le Savant et le Populaire, we decided to "limit the question to the forms of domination that are at play within a society" (18), in this case contemporary French society. This was a true 
française contemporaine. C'était choisir en sociologues. Les sociologies sont en effet le plus souvent nationales; le sociologue étudie, dans la langue qu'on y parle, la société dont il fait partie, à laquelle il « appartient », dans son ensemble ou dans un de ses sous-ensembles, régional ou local. Le sociologue se trouve ainsi confronté aux obstacles et aux limites que les particularités de son objet opposent à la généralisation et à la théorisation ; mais c'est aussi bien le cas de l'ethnologue ou de l'historien. II est seul en revanche à bénéficier des avantages et à pâtir des handicaps liés à la proximité : connaissance intime, familiarité avec une culture dont il est l'indigène, et le plus souvent le natif d'une part ; de l'autre risque d'ethnocentrisme, de préjugés liés à sa position sociale, et d'incapacité à mettre en question le cela-va-de-soi

caractéristique de la société qu'il étudie et de sa culture.

Fortement hiérarchisée et fortement intégrée, tant socialement que culturellement (instruction obligatoire, généralisation du français comme langue commune) cette société particulière présentait des caractéristiques contradictoires qui la rendaient et continuent de la rendre particulièrement intéressante. Mais la composition sociale des classes populaires a changé et la relecture du Savant et le Populaire invite à prendre en compte ces changements. Les propriétés des cultures dominées, la relation qu'elles entretiennent avec les cultures dominantes dépendent en effet des propriétés des groupes qui en sont le support. Depuis les années 1980 les effectifs des classes populaires traditionnelles ont décru ; c'est le cas, très fortement, des paysans, et, à un degré beaucoup moindre, des ouvriers (qui constituent encore en 2015 plus d'un cinquième de la population active) ; c'est aussi celui sociological choice. Sociologies are most often national in scope; the sociologist studies, in the language spoken in the country, the society of which he or she is a member, to which he or she "belongs," on the national, or on a regional or local scale. The sociologist therefore finds himself confronted with the obstacles and limitations the particularities of his object present to generalization and theorization; but this is also the case for ethnologists and historians. The sociologist is the only one, however, to enjoy advantages and suffer from the handicaps that come with proximity: on the one hand, intimate knowledge, familiarity with a culture that he belongs to, most often as a native; on the other hand, risks of ethnocentrism, prejudice tied to social position, and an inability to question the taken-for-granted aspects of the society he studies, and of its culture.

Strictly hierarchical and integrated, as much socially as culturally (compulsory education, the use of French as the common language), this society presented contradictory characteristics that made it and continue to make it particularly interesting. But the social composition of the working classes has changed and the rereading of Le Savant et le Populaire invites us to take these changes into account. The characteristics of the dominated cultures and their relationship with the dominant cultures depend on the properties of the groups that support them. Since the 1980s, the size of the traditional popular classes has diminished; this is especially the case with farmers and, to a lesser extent, workers (who still in 2015 account for more than one fifth of the labour force); this is also true of workers of peasant origin. At the same time, the population of more or less acculturated immigrants, 
des ouvriers issus de la paysannerie. Dans le même temps le nombre d'immigrés, porteurs plus ou moins acculturés de cultures étrangères, différentes par ces deux éléments essentiels que sont la langue et la religion, a augmenté. Dans quelle mesure peut-on considérer ces « cultures lointaines ", dès lors qu'elles sont devenues proches et font partie de cette société, comme des «cultures autres » au même titre que les cultures d'avant la colonisation ? Peut-on leur appliquer sans problème et sans risques le relativisme culturel ethnographique ? À la fois autonomes et dominées, ces cultures constituent un cas typique dont les concepts du Savant et le Populaire, comme autonomie et hétéronomie, devraient aider à démêler l'ambivalence.

Le relativisme culturel est un passage obligé, tant pour l'ethnologue des cultures populaires, qui doit prendre ses distances d'avec sa culture d'origine pour se rapprocher de celle qu'il étudie, que pour le sociologue lorsqu'il entend saisir ces cultures dans leur autonomie. Mais on risque de passer du relativisme culturel à un relativisme cognitif qui, sous sa forme extrême, repose sur un scepticisme radical pour lequel il est impossible de distinguer le vrai du faux parce que la vérité n'existe pas ${ }^{1}$. Le relativisme est dans l'air du temps ; il s'impose aux intellectual fashion victims, y compris aux sociologues par l'intermédiaire du sociologisme, qui entend aller toujours plus loin dans la réduction de tous les éléments de toutes les cultures à des constructions arbitraires,

1 Sur le relativisme des « négateurs », cf. Bernard Williams, Vérité et véracité Essai de généalogie, Paris, Gallimard, 2006, cité par Jacques Bouveresse $2008: 281-306$. bringing with them many foreign cultures, which are set apart by two essential elements, language and religion, has grown. To what extent can we consider these "faraway cultures," once they have drawn closer and become part of this society, to be "other cultures" in the same way as pre-colonial cultures? Can we apply ethnographic cultural relativism to them without difficulty and without risk? Both autonomous and dominated, these cultures constitute a typical case that the concepts elaborated in Le Savant et le Populaire, such as autonomy and heteronomy, should help to disentangle the ambivalence.

Cultural relativism is as necessary a passage for the ethnologist of popular cultures, who must maintain his distance from his culture of origin to draw nearer to the one he studies, as it is for the sociologist when he attempts to consider these cultures as autonomous. But we run the risk of passing from cultural relativism to a cognitive relativism which, in its extreme form, is based on a radical scepticism for which it is impossible to distinguish what is true from what is false because truth does not exist ${ }^{1}$. Relativism is fashionable; it applies to intellectual fashion victims, including sociologists through sociologism, which continually tries to go further in the reduction of every element of every culture to arbitrary constructions, all equally

1 For more information about "deniers," cf. Bernard Williams, Vérité et véracité Essai de généalogie, Paris, Gallimard 2006, cited by Jacques Bouveresse (2008: 281-306). 
également dépourvues de nécessité et d'efficacité pratiques et techniques, qu'il suffit de déconstruire pour expliquer.

Comme «culture », comme « société », « domination » est un de ces concepts usuels et mal définis dont on est obligé de se servir parce qu'ils désignent couramment les questions et les faits qui nous occupent. On s'est efforcé d'en préciser le sens non en cherchant des mots susceptibles d'exprimer leur nature, mais en repérant les choses et les faits, les « mécanismes » auxquels ils correspondent et qu'ils désignent ${ }^{2}$. « La sociologie de la culture a d'abord pour tâche de casser le monolithe que représente le concept de culture dominée » (Grignon \& Passeron 2015 : 140). Tâche inégalement ardue ; la notion d'alternance permet de distinguer entre les circonstances, les terrains, les interactions, etc. et invite à se donner les moyens empiriques de le faire. À l'inverse le terme opposé d'ambivalence lâche la bride à l'interprétation, en suggérant que les cultures populaires les plus autonomes sont encore, à quelque degré, des cultures dominées, qu'il y a toujours du Même dans l'Autre (et réciproquement). "L'espièglerie du démon interprétatif » (147) est sans limites : les descriptions les plus factuelles, les constats les plus réalistes et les plus objectifs sont matière à interprétation. On les interprète dès lors qu'on les intègre dans

2 «Les raisonnements logico-expérimentaux, qui ont leur fondement dans l'observation objective, sont amenés à ne se servir des termes que pour désigner les choses [...]. Les économistes littéraires [...] se complaisent à rechercher ce qu'est la valeur, le capital, etc. On n'arrive pas à leur mettre dans la tête que les choses sont tout et les mots rien. [...] En science, on suit une voie opposée à celle-là ; c'est-à-dire qu'on s'occupe d'abord de la chose, et qu'ensuite ou lui cherche un nom » (Pareto $1917: 48,53,55$ ) deprived of necessity and practical and technical efficiency, that need only be deconstructed to be explained.

Like "culture" and "society," "domination" is one of those common but poorly defined concepts that we are obliged to use because they usually denote the questions and facts that we are concerned with. We strove to pinpoint their meaning not by looking for words that might explain their nature, but by collecting the things and facts-the "mechanisms'-to which they correspond and that they denote ${ }^{2}$. "Sociology of culture has to first break the monolith represented by the concept of dominated culture" (Grignon \& Passeron 2015: 140). This is a task that is unequally difficult to accomplish; the notion of alternation allows us to distinguish between circumstances, fields, interactions, etc., and invites us to find empirical methods with which to do so. Conversely, the notion of ambivalence leaves the door open for interpretation, by suggesting that the most autonomous working class cultures are still, to some degree, dominated-that there is still some of the Same in the Other (and vice versa). "The mischievousness of the interpretative demon" (147) knows no bounds: the most factual descriptions, the most realistic and objective observations are open to interpretation. We interpret them as soon as we analyse them, seek to explain

2 "Logical-experimental reasonings, which have their base in objective observation, end up using terms only to designate things [...]. Literary economists $[. .$.$] indulge themselves with researching what is value, what is$ capital, etc. We cannot get them to understand that things are everything and words are nothing. [...] In science, we follow the opposite path; that is to say, we concern ourselves with the thing in question first, then we try to find a name for it" (Pareto, French version, 1917: 48, 53, 55). 
l'analyse, qu'on cherche à les expliquer, qu'on les commente, qu'on les présente ; la sociologie des cultures risque ainsi de basculer du côté des « théories du soupçon », des idéologies

et des pseudo-sciences.

La définition des concepts renvoie à la question des relations entre les langages populaires et la langue dans laquelle le sociologue les transcrit. Comment faire parler les indigènes? Pour rendre leur discours intelligible, il faut le traduire ; mais on ne peut le traduire sans l'altérer, sans lui faire perdre son sens originel. George Sand a clairement formulé cette aporie (291, note 5). Le sociologue pense et s'exprime spontanément, naturellement, dans cette variante dominante du langage naturel qu'est la langue lettrée, qui est la langue de sa culture, sa langue maternelle, celle dans laquelle il a été formé, la langue de son milieu professionnel et la langue du public cultivé auquel ses écrits sont destinés. Alors que les discours populaires, vernaculaires et «parlures », sont le plus souvent oraux, la sociologie s'écrit. Le sociologue ne peut se passer des ressources de " cette langue doublement écrite qu'est la langue littéraire » (291), en particulier de son pouvoir d'évocation qui l'aide à dégager ses concepts de l'observation et qui, en faisant parler ces concepts à l'imagination, permet de se figurer ce qu'ils représentent, et donc de commencer à savoir ce qu'ils désignent ; témoin ces récits à la fois suggestifs et significatifs qui donnent à penser en donnant à voir, qu'on trouve chez Richard Hoggart, chez Marcel Maget ou chez Marcel Granet (Grignon 2001). Mais ce pouvoir d'évocation favorise les dérives interprétatives, en particulier celles qui sont liées à l'association libre des mots, des images et des idées. II faut donc le contrôler en s'efforçant de combiner them, comment on them, present them; sociology of culture thereby comes dangerously close to "theories of suspicion," to ideologies and to pseudo-science.

The definition of concepts leads back to the question of the relationship between working-class languages and the language in which the sociologist transcribes them. How can he represent the way subjects speak? To make their speech intelligible, one must translate it; but one cannot translate it without altering it, without causing it to lose its original meaning. George Sand very clearly formulated this aporia (291, note 5). The sociologist thinks and expresses himself spontaneously, naturally, in this dominant form of natural language that is the language of the well-read, the language of his culture, his mother tongue, the language in which he has been trained, that of his professional milieu and of the cultured audience to which his writings are directed. While popular speeches, vernaculars, and "lingoes," are most often oral, sociology is written. The sociologist cannot do without the resources of "literary language which is doubly written" (291), especially its evocative power which helps to elaborate his concepts from observation and which, by tying these concepts to the imagination, allows what they represent to be imagined, and thus allows us to begin to know what they mean; take for example those accounts that are both suggestive and meaningful, which make the reader think by giving him something to see, cf. the works of Richard Hoggart, Marcel Maget, or Marcel Granet (Grignon, 2001). But this evocative power favours interpretative drifts, particularly those which are tied to the free association of words, images and ideas. 
les principes et les exigences opposés de l'écriture littéraire et de l'écriture scientifique. Alors que la connotation est au principe de la capacité évocatrice de la langue littéraire, la langue scientifique repose sur la dénotation. Le sens d'un terme scientifique dépend de sa capacité déictique ; on sait ce qu'un mot scientifique signifie quand on sait précisément, sans ambiguïté, ce qu'il désigne (Servien 1935). On ne s'autorisera donc à jouer sur les connotations que pour les mots dont on sait ce qu'ils dénotent. On sera particulièrement vigilant à l'égard des connotations que les mots savants suscitent à toutes les étapes et chez tous les acteurs de la recherche, chez l'enquêteur et chez les enquêtés, chez le sociologue qui rédige et chez le lecteur dont il anticipe les attentes et les réactions.

Dès lorsqu'on utilise les ressources et les procédés del'écriture littéraire, on risque de céder à l'influence et à l'attraction de la littérature. Difficile, pour le sociologue qui écrit, de ne pas se sentir et de ne pas se vouloir écrivain ; de même que l'intellectuel, l'écrivain sommeille dans le sociologue. Faute de renoncer à peindre, le sociologue, comme l'historien, risque de renoncer à expliquer, de confondre, comme dit Taine, l'art et l'analyse, la réalité et la fiction, de sacrifier l'exactitude à l'illusion de la vérité (1858). Lorsque les caractères qui les définissent ont été déterminés pour leur pouvoir évocateur, les types que la sociologie s'efforce de constituer se rapprochent des types littéraires et deviennent des portraits. La sociologie risque alors de reprendre à son compte les représentations littéraires de l'ouvrier, du paysan ou de l'immigré, tant folkloristes et populistes que misérabilistes. " Le narcissisme d'auteur offre un bastion inexpugnable à l'ethnocentrisme de classe » (Grignon \& Passeron 2015 : 313).
It is therefore necessary to control it by trying to combine the conflicting principles and demands of literary and scientific writings. While the evocative power of literary language is based on connotation, scientific language depends on denotation. The meaning of a scientific word depends on its deictic capacity; we know what a scientific word means when we know precisely, without ambiguity, what it refers to (Servien, 1935). We will therefore allow ourselves to play with the connotations only for words whose denotation is known. We will be particularly careful regarding the connotations evoked by scholarly terms at every step of the research and for all of those who participate in it, including the interviewer and the interviewees, the sociologist who writes, and the reader whose expectations and reactions he anticipates.

As soon as one makes use of the resources and processes of literary writing, one risks giving in to the influence and attraction of literature. It is difficult for the sociologist who writes not to feel like or want to become an author; just as is the case with the intellectual, an author sleeps within the sociologist. Unless he stops attempting to paint a picture, the sociologist, like the historian, risks foregoing explaining, mixing art with analysis, reality with fiction, sacrificing exactitude to the illusion of truth, as Taine says (1858). When the characteristics that define them have been determined by their evocative power, the types that sociology tries to create approximate literary types and become portraits. Sociology therefore risks taking on literary representations of the worker, the farmer, or the immigrant, as folkloric and populist as they are miserabilist. "The author's narcissism offers an impregnable bastion to class ethnocentrism" (Grignon \& Passeron 2015: 313). 
Les problèmes de traduction et d'écriture invitent à poursuivre l'exercice épistémologique du Savant et le Populaire ${ }^{3}$. Les langues que les sciences emploient, dans lesquels elles pensent et s'expriment, sont un critère déterminant de leur différenciation et de leur classement, sinon de leur hiérarchie. Chaque science, chaque spécialité se distingue par les mots qui lui sont propres. Sous ce rapport, les langages scientifiques s'apparentent aux dialectes, argots de métiers, langues régionales, patois locaux, etc. Si particuliers, si savants qu'ils soient, si incompréhensibles pour le profane, ce sont des variantes, des versions du langage naturel. Leur traduction en langage ordinaire, à des fins de vulgarisation ou d'enseignement, pose les mêmes problèmes que la traduction d'un discours ou d'un texte en langue « étrangère ". Mais les différences entre les langues scientifiques ne se réduisent pas à ces différences de lexique. La principale opposition, fondamentale, est entre les sciences qui pensent en mathématiques, et les sciences qui pensent en langage naturel : d'un côté les sciences de la matière, qui expliquent en formulant des lois universelles qui permettent de prévoir de l'autre les sciences de l'homme, qui expliquent en trouvant les causes, en reconstituant les enchaînements causals qui se déroulent dans un temps irréversible (entre les deux, les sciences du vivant, partagées entre physique et histoire - la biologie moléculaire versus la biologie des organismes ou de

l'évolution).

3 Ce que j'ai fait dans deux ouvrages collectifs, issus eux aussi de séminaires (Grenier, Grignon, Menger 2001 ; Grignon \& Kordon 2009).
Translation and writing difficulties encourage us to pursue the epistemological exercise of Le Savant et le Populaire ${ }^{3}$. The languages used by the sciences, in which they think and express, are a determinative criterion of their differentiation and their categorization, if not of their hierarchy. Each science, each specialization, can be distinguished by its own words. In this respect, scientific languages have much in common with dialects, professional jargons, regional languages, local patois, etc. As particular, scholarly, and incomprehensible for the layman as they may be, they are variants of natural language. Their translation into ordinary language, for reasons of vulgarisation or instruction, poses the same problems as the translation of a speech or text into a "foreign" language. But the differences between scientific languages cannot be reduced to lexical differences. The principal, fundamental, opposition divides the sciences that think in mathematics and those that think in natural language: on one hand, the sciences of matter, which explain by formulating universal laws that allow prediction; on the other hand, the human sciences, which explain by finding causes, and reconstituting causal sequences that take place in an irreversible time (between the two is biological science, which is split between physics and history-molecular biology versus evolutionary biology or the biology of organisms).

3 Which I have done in two collective works, themselves products of seminars (Grenier, Grignon, Menger 2001; Grignon \& Kordon 2009). 
Sous ce rapport la sociologie appartient à la même famille, à la même sous-espèce de sciences que l'ethnologie et l'histoire, celle des sciences de l'homme collectif. Mais, sous peine d'oublier que les cultures populaires sont aussi des cultures dominées, le sociologue qui se fait ethnologue doit rester sociologue. II lui faut pour cela combiner les méthodes quantitatives et les méthodes qualitatives : recourir au recueil et au traitement statistique des données pour établir à défaut de lois des régularités (le sociologue use alors des mathématiques, mais comme outil et non comme langue) ; expliquer ces régularités en reconstituant (par l'interview, l'observation, les études de cas) les processus au terme desquels se réalisent (ou non) les relations de cause (variables trieuses) à effet (variables triées) que suggèrent les relations statistiques. En reconstituant des histoires singulières, le sociologue se donne les moyens de savoir comment les déterminismes sociaux agissent, mais aussi pourquoi il leur arrive de ne pas agir, comment des individus d'exception ont pu échapper au destin social qui leur était réservé. C'est le cas de Richard Hoggart ; l'histoire de sa vie permet de savoir pourquoi les mécanismes de la reproduction n'ont pas fonctionné, et, du même coup, de mieux savoir comment ils fonctionnent (Hoggart 2013). Mais pour le sociologue, les individus d'exception ne sont pas uniques ; en comparant leurs histoires respectives, il peut les regrouper en fonction de traits communs spécifiques, constituer des familles de cas, et revenir ainsi de l'individuel au collectif.
In this regard, sociology belongs to the same family, the same subcategory of science as ethnology and history, that of collective human science. But, at the risk of forgetting that popular cultures are also dominated cultures, the sociologist who wants to be an ethnologist must remain a sociologist. That is why he must combine quantitative and qualitative methods: collecting and processing statistical data in order to establish regularities for lack of laws (the sociologist therefore uses mathematics, but as a tool and not as a language); explaining these regularities by reconstructing (through interviews, observations, case studies, etc.) the processes at the end of which the statistical relationships between the cause (explanatory variables) and effect (explained variables) take place (or not). By reconstructing individual stories, the sociologist gives himself the means of knowing how social determinisms act, but also why they sometimes do not act, and how some exceptional individuals can escape their social destiny. This is the case with Richard Hoggart; the story of his life allows us to know why the mechanisms of reproduction did not work, and, at the same time, to better understand how they function (Hoggart 1988, translated in French: 1991, 2013). But, for the sociologist, exceptional individuals are not unique; by comparing their respective stories, he can group them according to specific traits they share, putting together case clusters, thereby returning to the collective from the individual. 


\section{Références bibliographiques}

Aron Raymond (1983). Mémoires. Paris, Julliard.

BAKHTINE Mikhaïl (1970). L'CEuvre de François Rabelais et la culture populaire au Moyen Âge et sous la Renaissance. Paris, Gallimard.

BECKER Howard (1988). Les Mondes de l'art. Traduit de l'anglais par Jeanne Bouniort. Paris, Flammarion.

Bellavance Guy, Boivin Micheline, SanterRe Lise (dir.) (2000). Démocratisation de la culture ou démocratie culturelle? Deux logiques d'action publique. Québec, Éditions de l'IQRC.

BoIs Géraldine (2008). « Le consentement à la domination littéraire. Degrés et diversité de ses formes chez les écrivains "les moins reconnus" de l'univers littéraire ». Tracés, $14: 55-76$.

BouRdieu Pierre (1979). La Distinction. Critique sociale du jugement. Paris, Minuit.

Bourdieu Pierre (1984). Questions de sociologie. Paris, Minuit.

BOURDIEU Pierre (1988). « Entretien recueilli par Beate Krais ». In BOURDIEU Pierre, Chamboredon Jean-Claude, PAsseron Jean-Claude, Le Métier de sociologue. Préalables épistémologiques. Paris, Éditions de l'EHESS (cinquième édition).

Bourdieu Pierre (1989). La Noblesse d'État. Paris, Minuit.

\section{References}

ARON Raymond (1990). Memoirs: Fifty Years of Political Reflection. English Translation by George Holoch. New York, Holmes and Meier.

BAKHTIN Mikhail M. (1968) [1965]. Rabelais and His World. English translation by Hélène Iswolsky. Cambridge, MA, MIT Press.

BECKER Howard (1982). Art Worlds. Los Angeles, University of California Press.

Bellavance Guy, Boivin Micheline, Santerre Lise (eds.) (2000) Démocratisation de la culture ou démocratie culturelle? Deux logiques d'action publique. Québec, Éditions de l'IQRC.

Bols Géraldine (2008). "Le consentement à la domination littéraire. Degrés et diversité de ses formes chez les écrivains 'les moins reconnus' de l'univers littéraire." Tracés, 14: 55-76.

BOURDIEU Pierre (1984). Distinction: A Social Critique of the Judgement of Taste. English translation by Richard Nice. Cambridge, Mass., Harvard University Press.

BouRdieU Pierre (1993). Sociology in Question. English Translation by Richard Nice. London, SAGE.

BOURDIEU Pierre (1988). "Entretien recueilli par Beate Krais." In BOURDIEU Pierre, Chamboredon Jean-Claude, PAsseron Jean-Claude, Le Métier de sociologue. Préalables épistémologiques. Paris, Éditions de l'EHESS (fifth issue).

BouRdieu Pierre (1996). The State Nobility: Elite Schools in the Field of Power. English translation by Lauretta C. Clough. Palo Alto, Stanford University Press. 
BOURDIEU Pierre (1993). «Les contradictions de l'héritage ». In Bourdieu Pierre (dir.), La Misère du monde. Paris, Seuil : 711-718.

BouRdieu Pierre (1998) [1992]. Les Règles de l'art. Genèse et structure du champ littéraire. Paris, Seuil.

BouRdieu Pierre (1998). La Domination masculine. Paris, Seuil.

BouRdieu Pierre (2003) [1997]. Méditations pascaliennes. Paris, Seuil.

Bourdieu Pierre, Chamboredon Jean-Claude, PASSERON Jean-Claude (1968). Le Métier de sociologue. Paris, Mouton.

Bourdieu Pierre \& PAsseron Jean-Claude (1964). Les Héritiers. Les étudiants et la culture. Paris, Minuit.

BOURDIEU Pierre \& PASSERON Jean-Claude (1970). La Reproduction. Éléments pour une théorie du système d'enseignement. Paris, Minuit.

BOURDIEU Pierre \& WACQUANT Loïc (2014). Invitation à la sociologie réflexive. Paris, Seuil.

BOUTIER Jean (2008). «Quelques réflexions rétrospectives sur les histoires de la "culture populaire" ». Journée d'étude « Le Savant et le Populaire, 1989-2008. Retour sur un débat en suspens ». SHADYC EHESS Marseille (non publié).
BOURDIEU Pierre (1993). "The Contradictions of Inheritance." In BOURDIEU Pierre (ed.), The Weight of the World: Social Suffering in Contemporary Society. English translation by Priscilla Parkhurst Ferguson and al. Cambridge, Polity : 507-513.

Bourdieu Pierre (1996). The Rules of Art: Genesis and Strucure of the Literary Field. English translation by Susan Emmanuel. Palo Alto, Stanford University Press.

BourdieU Pierre (2002). Masculine Domination. English translation by Richard Nice. Palo Alto, Stanford University Press.

Bourdieu Pierre (2000). Pascalian Meditations. English Translation by Richard Nice. Palo Alto, Stanford University Press.

Bourdieu Pierre, Chamboredon Jean-Claude, Passeron Jean-Claude (1991). The Craft of Sociology: Epistemological Preliminaries. English Translation by Richard Nice. Berlin, Gruyter.

Bourdieu Pierre \& PASSERON Jean-Claude (1977). Reproduction in Education, Society and Culture. English Translation by Richard Nice. Beverly Hills, Sage Publications.

BOURDIEU Pierre \& PASSERON Jean-Claude (1979). The Inheritors: French Students and their Relations to Culture. English Translation by Richard Nice. Chicago, University of Chicago Press.

BouRdieU Pierre \& WACQUANT Loïc (2014). Invitation à la sociologie réflexive. Paris, Seuil.

BOUTIER Jean (2008). "Quelques réflexions rétrospectives sur les histoires de la 'culture populaire'." Workshop "Le Savant et le Populaire, 19892008. Retour sur un débat en suspens." SHADYC, EHESS Marseille. 
BOUVERESSE Jacques (2008). « Le besoin de croyance et le besoin de vérité ». Agone, 38-39: 281-306.

BuRke Peter (1978). Popular Culture in Early Modern Europe. Londres, Temple Smith.

Buscatto Marie (2014). Sociologies du genre. Paris, Armand Colin.

BusıNO Giovanni (2006). «Entretien avec Dominique Schnapper ». Revue européenne des sciences sociales, XLIV(135). [En ligne] http://ress. revues.org/271 [consulté le 12 octobre 2016].

Casanova Pascale (2008) [1999]. La République mondiale des lettres. Paris, Seuil.

ChAPOULIE Jean-Michel (1991). « La seconde fondation de la sociologie française, les États-Unis et la classe ouvrière ». Revue française de sociologie 32(3) : 321-364.

CHARTIER Roger (2001). «Culture écrite et littérature à l'âge moderne ». Annales. Histoire, Sciences sociales, 56(4) : 783-802.

COHEN Déborah (2010). La Nature du peuple. Les formes de l'imaginaire social (XVIII $/ X X I^{e}$ siècles). Seyssel, Champ Vallon.

COLLECTIF (1988). « Histoire et sciences sociales. Un tournant critique ? ». Annales ESC, 2 : 291-293.

Collectif Révoltes logiques (1984). L'Empire du sociologue. Paris, La Découverte.

Collovald Annie (1988). «Identité(s) stratégiques(s) », Actes de la recherche en sciences sociales, $73: 29-40$.

Connell Raewyn (1995). Masculinities. Cambridge, Polity Press.
BoUVERESSE Jacques (2008). "Le besoin de croyance et le besoin de vérité." Agone, 38-39: 281-306.

Burke Peter (1978). Popular Culture in Early Modern Europe. London, Temple Smith.

Buscatto Marie (2014). Sociologies du genre. Paris, Armand Colin.

Busıno Giovanni (2006). "Entretien avec Dominique Schnapper." Revue européenne des sciences sociales, XLIV(135). [On line] http://ress. revues.org/271 [accessed on 12 october 2016].

Casanova Pascale (2005). The World Republic of Letters. English translation by Malcolm B. DeBevoise. Harvard, Harvard University Press.

ChAPOULIE Jean-Michel (1991). "La seconde fondation de la sociologie française, les États-Unis et la classe ouvrière." Revue française de sociologie 32(3): 321-364

CHARTIER Roger (2001). "Culture écrite et littérature à l'âge moderne." Annales. Histoire, Sciences sociales, 56(4): 783-802.

COHEN Déborah (2010). La Nature du peuple. Les formes de l'imaginaire social (XVIII/XXI siècles). Seyssel, Champ Vallon.

Collectif (1988). "Histoire et sciences sociales. Un tournant critique?". Annales ESC, 2: 291-293.

Collectif Révoltes logiques (1984). L'Empire du sociologue. Paris, La Découverte.

Collovald Annie (1988). "Identité(s) stratégiques(s)." Actes de la recherche en sciences sociales, 73: 29-40.

Connell Raewyn (1995). Masculinities. Cambridge, Polity Press. 
CORNu Tanguy (2008). « L'ambiguïté du concept de domination symbolique dans Le Savant et le Populaire ». Journée d'étude "Le Savant et le Populaire, 1989-2008. Retour sur un débat en suspens ». SHADYC, EHESS Marseille (non publié).

CoUlANGEON Philippe \& DuvaL Julien (2013). Trente ans après La Distinction de Pierre Bourdieu. Paris, La Découverte.

CoUlANGeON, Philippe \& Duval Julien (2013). «Introduction ». In EID. (dir.), Trente ans après La Distinction de Pierre Bourdieu. Paris, La Découverte.

Daudet Alphonse (1868). Le Petit Chose. Paris, Pierre-Jules Hetzel.

Debeauvais Michel (1976). L'Université ouverte: les dossiers de Vincennes. Grenoble, Presses Universitaires de Grenoble.

DrAGOMIR Lucia (2011). « L'Union des écrivains. Un modèle institutionnel et ses limites ». Vingtième siècle, $109: 59-70$.

DucournaU Claire (2017). « Les deux (ou trois) carrières de Richard Hoggart. De la fondation des cultural studies aux appropriations de la sociologie française ». Revue d'anthropologie des connaissances, 11(3) : 263-282.

DUMONT Fabienne \& SofIO Séverine (2007). « Esquisse d'une épistémologie de la théorisation féministe en art ». Cahiers du genre, 43 : 17-43.

DuVAL Julien (2010). «Distinction studies ». Actes de la recherche en sciences sociales, 181-182:146-156.

EliAs Norbert (1991). La Société des individus. Traduit de l'allemand par Jeanna Etoré. Paris, Fayard.
CoRnu Tanguy (2008). "L'ambiguïté du concept de domination symbolique dans Le Savant et le Populaire." Workshop "Le Savant et le Populaire, 1989-2008. Retour sur un débat en suspens." SHADYC, EHESS Marseille.

Coulangeon Philippe \& DuvaL Julien (2013). Trente ans après La Distinction de Pierre Bourdieu. Paris, La Découverte.

Coulangeon, Philippe \& Duval Julien (2013). "Introduction." In EID. (eds.), Trente ans après La Distinction de Pierre Bourdieu. Paris, La Découverte.

DAUdET Alphonse (1878). Little Good-For-Nothing. English translation by Mary Neal Sherwood. Boston, Estes and Lauriat.

Debeauvais Michel (1976). L'Université ouverte: les dossiers de Vincennes. Grenoble, Presses Universitaires de Grenoble.

DragomiR Lucia (2011). "L'Union des écrivains. Un modèle institutionne et ses limites." Vingtième siècle, 109: 59-70.

DucournaU Claire (2017). "Les deux (ou trois) carrières de Richard Hoggart. De la fondation des cultural studies aux appropriations de la sociologie française." Revue d'anthropologie des connaissances, 11(3): 263-282.

DUMONT Fabienne \& SoFIO Séverine (2007). "Esquisse d'une épistémologie de la théorisation féministe en art." Cahiers du genre, 43: 17-43.

DUVAL Julien (2010). "Distinction studies." Actes de la recherche en sciences sociales, 181-182: 146-156.

ELIAS Norbert (1991). The Society of Individuals. English Translation by Edmund Jephcott. Oxford, Basil Blackwell. 
FABIANI Jean-Louis (dir.) (2001). Le Goût de l'enquête. Pour Jean-Claude Passeron. Paris, L'Harmattan.

FossÉ-Polık Claude (2006). Aux frontières du champ littéraire. Sociologie des écrivains amateurs. Paris, Économica.

Foucault Michel (1973). Moi, Pierre Rivière ayant égorgé ma mère, ma sœur et mon frère... Paris, Gallimard/Julliard.

Foucault Michel (1994). Dits et écrits, t. 1 et 2. Paris, Gallimard.

Gaboriau Philippe (1995). Le Tour de France et le vélo. Histoire sociale d'une épopée contemporaine. Paris, L'Harmattan.

GabORIAU Philippe (2003). Les Spectacles sportifs. Grandeurs et décadences. Paris, L'Harmattan.

GinzBuRg Carlo (1980) [1976]. Le Fromage et les vers. L'univers d'un meunier $d u x v l^{e}$ siècle [II formaggio e $i$ vermi. II cosmo di un mugnaio del Cinquecento, Turin, Einaudi]. Traduit de l'italien par Monique Aymard. Paris, Flammarion.

Grenier Jean-Yves, Grignon Claude, Menger Pierre-Michel (dir.) (2001). Le Modèle et le récit. Paris, Maison des Sciences de l'Homme.

GriGNON Claude (1996). « Le savant et le lettré, ou l'examen d'une désillusion », Revue européenne des sciences sociales, $103: 81-98$.

GRIGNON Claude (2001). « La formalisation et les sciences du récit, le cas de la sociologie ». In GrenIER Jean-Yves, Grignon Claude, Menger Pierre-Michel (dir.), Le Modèle et le récit. Paris, Maison des Sciences de l'Homme : 7-43.
FABIANI Jean-Louis (ed.) (2001). Le Goût de l'enquête. Pour Jean-Claude Passeron. Paris, L'Harmattan.

FossÉ-PolıaK Claude (2006). Aux frontières du champ littéraire. Sociologie des écrivains amateurs. Paris, Économica.

FouCAULt Michel (1982). Pierre Rivière, having slaughtered my mother, my sister, and my brother... A Case of Parricide in the 19th Century. English Translation by Frank Jellinek. Lincoln, University of Nebraska Press.

Foucault Michel (1994). Dits et écrits, t. 1 et 2. Paris, Gallimard.

GaboRIau Philippe (1995). Le Tour de France et le vélo. Histoire sociale d'une épopée contemporaine. Paris, L'Harmattan.

GabORIAU Philippe (2003). Les Spectacles sportifs. Grandeurs et décadences. Paris, L'Harmattan.

GinzBURG Carlo (1980). The Cheese and the Worms: the Cosmos of a Sixteenth-Century Miller. English Translation by Ann Tedeschi et John Tedeschi. Baltimore, Johns Hopkins University Press.

Grenier Jean-Yves, Grignon Claude, Menger Pierre-Michel (eds.) (2001). Le Modèle et le récit. Paris, Maison des Sciences de l'Homme.

GrignON Claude (1996). "Le savant et le lettré, ou l'examen d'une désillusion," Revue européenne des sciences sociales, 103: 81-98.

GriGnON Claude (2001). "La formalisation et les sciences du récit, le cas de la sociologie." In Grenier Jean-Yves, Grignon Claude, Menger Pierre-Michel (eds.), Le Modèle et le récit. Paris, Maison des Sciences de I'Homme: 7-43. 
GRIGNon Claude \& Kordon Claude (dir.) (2009). Sciences de l'homme et sciences de la nature, essais d'épistémologie comparée. Paris, Maison des Sciences de l'Homme.

GriGnON Claude \& PASSERON Jean-Claude (1982). Sociologie de la culture et sociologie des cultures populaires. Paris, Documents du GIDES, 4.

Grignon Claude \& Passeron Jean-Claude (1985). Enquête. Cahiers du CERCOM, 1 («À propos des cultures populaires »). [En ligne] https:// enquete.reveues.org/2 [consulté le 26 juin 2017].

Grignon Claude \& Passeron Jean-Claude (2015) [1989]. Le Savant et le Populaire. Misérabilisme et populisme en sociologie et en littérature. Paris, Seuil, « Points » [1re éd. Gallimard/Seuil, « Hautes études »]. En espagnol : Grignon Claude \& Passeron Jean-Claude (1991). Lo culto y lo popular : miserabilismo y populismo en sociologia y en literatura. Traduction de María Sonderéguer. Buenos Aires, Ediciones Nueva Vision : Grignon Claude \& Passeron Jean-Claude (1992). Lo culto y lo popular: miserabilismo y populismo en sociologia y en literatura. Traduction de Fernando Alvarez-Uria et Julia Varela. Madrid, Las Ediciones de La Piqueta.

Grignon Claude, Collovald Annie, Pudal Bernard, Sawicki Frédéric (1991). « Un savant et le populaire. Entretien avec Claude Grignon ». Politix, 13 : 35-42.

Gruel Louis (2004). La Rébellion de 68. Une relecture sociologique. Rennes, Presses Universitaires de Rennes.

GuilLaumin Colette (2002) [1972]. L'Idéologie raciste. Paris, Gallimard.

Hall Stuart \& JefFerson Tony (dir.) (1976). Resistance through Rituals : Youth Subcultures in Post-War Britain. Londres, Hutchinson.
GriGnON Claude \& Kordon Claude (eds.) (2009). Sciences de l'homme et sciences de la nature. Essais d'épistémologie comparée. Paris, Maison des Sciences de l'Homme.

GriGnON Claude \& PASSERON Jean-Claude (1982). Sociologie de la culture et sociologie des cultures populaires. Paris, Documents du GIDES, 4.

Grignon Claude \& PAsseron Jean-Claude (1985). Enquête. Cahiers du CERCOM, 1 ("À propos des cultures populaires"). [On line] https:// enquete.reveues.org/2 [accessed on 26 june 2017].

Grignon Claude \& PASSERON Jean-Claude (2015) [1989]. Le Savant et le Populaire. Misérabilisme et populisme en sociologie et en littérature. Paris, Seuil, "Points" [1're éd. Gallimard/Seuil, "Hautes études"]. In Spanish: GRIGNON Claude \& PASSERON Jean-Claude (1991). Lo culto y lo popular: miserabilismo y populismo en sociologia y en literatura, Buenos Aires, Ediciones Nueva Vision. Translated from French to Spanish by María Sonderéguer); Grignon Claude \& PASSERON Jean-Claude (1992). Lo culto y lo popular: miserabilismo y populismo en sociologia y en literatura. Translated from French to Spanish by Fernando Alvarez-Uria y Julia Varela. Madrid, Las Ediciones de La Piqueta.

Grignon Claude, Collovald Annie, Pudal Bernard, Sawicki Frédéric (1991). "Un savant et le populaire. Entretien avec Claude Grignon." Politix, 13: 35-42.

GRUEL Louis (2004). La Rébellion de 68. Une relecture sociologique. Rennes, Presses Universitaires de Rennes.

Guillaumin Colette (2002) [1972]. L'Idéologie raciste. Paris, Gallimard.

HaLl Stuart \& JefFerson Tony (eds.) (1976). Resistance through Rituals: Youth Subcultures in Post-War Britain. London, Hutchinson. 
Hammou Karim (2008). «Penser le pouvoir avec Le Savant et le Populaire». Journée d'étude « Le Savant et le Populaire, 1989-2008. Retour sur un débat en suspens ». SHADYC, EHESS Marseille (non publié).

HEINICH Nathalie (2000) [1991]. Être écrivain. Paris, La Découverte.

Hoggart Richard (1970a). La Culture du pauvre. Étude sur le style de vie des classes populaires en Angleterre. Traduit de l'anglais par Françoise Garcia, Jean-Claude Garcia et Jean-Claude Passeron, présentation et index de Jean-Claude Passeron (titre original The Uses of Literacy : Aspects of Working Class Life). Paris, Minuit.

HoggaRT Richard (1970b). Speaking to Each Other, vol. 1. Londres, Chatto et Windus.

Hoggart Richard (2013) [1991]. 33 Newport Street. Autobiographie d'un intellectuel issu des classes populaires anglaises. Traduit de l'anglais par Christiane Grignon \& Claude Grignon avec la collaboration de Christopher Todd, présentation de Claude Grignon. Paris, Seuil, « Points »

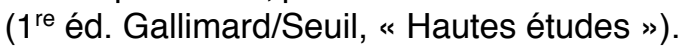

KALIFA Dominique (2005). « Les historiens français et le "populaire" ». Hermès, $42: 54-59$.

KRÉFA Abir (2013). “ La quête de l'autonomie littéraire en contexte autoritaire : le cas des écrivains tunisiens ». Sociologie, $4: 395-411$.

KRÉFA Abir (2013). Activités littéraires et rapports sociaux de sexe : le cas des écrivains tunisiens (thèse de doctorat en sociologie). Lyon, Université Lyon 2.

KRÉFA Abir (2014). «Entre injonctions à dire et à taire le corps : les voies étroites de la reconnaissance littéraire pour les écrivaines tunisiennes ». Ethnologie française, 44(4) : 631-642.
Hammou Karim (2008). "Penser le pouvoir avec Le Savant et le Populaire." Workshop "Le Savant et le Populaire, 1989-2008. Retour sur un débat en suspens." SHADYC, EHESS Marseille.

HEINICH Nathalie (2000) [1991]. Être écrivain. Paris, La Découverte.

HoggaRt Richard (1957). The Uses of Literacy: Aspects of Working Class Life. London, Essential Books.

HoggaRT Richard (1970). Speaking to Each Other, vol. 1. London, Chatto et Windus.

Hoggart Richard (1988). A Local Habitation: Life and Times, 1918-1940. London, Chatto \& Windus.

KaLIFA Dominique (2005). "Les historiens français et le 'populaire'." Hermès, 42: 54-59.

KRÉFA Abir (2013). "La quête de l'autonomie littéraire en contexte autoritaire: le cas des écrivains tunisiens." Sociologie, 4: 395-411.

KRÉFA Abir (2013). Activités littéraires et rapports sociaux de sexe: le cas des écrivains tunisiens (PhD. dissertation, Sociology). Lyon, Université Lyon 2.

KRÉFA Abir (2014). "Entre injonctions à dire et à taire le corps: les voies étroites de la reconnaissance littéraire pour les écrivaines tunisiennes." Ethnologie française, 44(4): 631-642. 
LAGRAVE Rose-Marie (1980). Le Village romanesque. Le Paradou, Actes Sud, « Espace-temps ».

LAGRAVE Rose-Marie (1988). "Mensonge romanesque et vérité des romanciers. Une relecture du Village Romanesque ». Études Rurales, $109: 55-73$.

LAGRAVE Rose-Marie (2009). « Filiations intellectuelles et espérance sociale. Figure et œuvre de Placide Rambaud ». Études rurales, 183 : 51-66.

LAGRAVE Rose-Marie (2010). «Se ressaisir ». Genre, Sexualité \& Société 4 : 1-17. [En ligne] http://gss.revues.org

LAHIRE Bernard (2004). La Culture des individus : dissonances culturelles et distinction de soi. Paris, La Découverte.

LAHIRE Bernard (2008). La Raison scolaire. École et pratiques d'écriture, entre savoir et pouvoir. Rennes, Presses Universitaires de Rennes.

LAHIRE Bernard (2012). Monde pluriel. Penser l'unité des sciences sociales. Paris, La Découverte.

LAMONT Michèle (1995). La Morale et l'argent : les valeurs des cadres en France et aux États-Unis. Paris, Métailié.

LAMONT Michèle (2013). « En quoi Bourdieu a-t-il été utile à notre réflexion ? Le cas des États-Unis ». In CoULANGeON Philippe \& DuvaL Julien (dir.), Trente ans après La Distinction de Pierre Bourdieu. Paris, La Découverte : 59-68.

LEVI Giovanni (1989). Le Pouvoir au village. Histoire d'un exorciste dans le Piémont du XVII siècle. Paris, Gallimard.
LAgRAVE Rose-Marie (1980). Le Village romanesque. Le Paradou, Actes Sud, "Espace-temps."

LAGRAVE Rose-Marie (1988). "Mensonge romanesque et vérité des romanciers. Une relecture du Village Romanesque." Études Rurales, 109: 55-73.

LAgrave Rose-Marie (2009). "Filiations intellectuelles et espérance sociale. Figure et œuvre de Placide Rambaud." Études rurales, 183: 5166

Lagrave Rose-Marie (2010). "Se ressaisir." Genre, Sexualité \& Société, 4 1-17. [On line] http://gss.revues.org

LAHIRE Bernard (2004). La Culture des individus: dissonances culturelles et distinction de soi. Paris, La Découverte.

LAHIRE Bernard (2008). La Raison scolaire. École et pratiques d'écriture, entre savoir et pouvoir. Rennes, Presses Universitaires de Rennes.

LAHIRE Bernard (2012). Monde pluriel. Penser l'unité des sciences sociales. Paris, La Découverte.

LAMONT Michèle (1994). Money, Morals, and Manners: The Culture of the French and the American Upper-Middle Class. Chicago, University Of Chicago Press.

LAMONT Michèle (2013). "En quoi Bourdieu a-t-il été utile à notre réflexion? Le cas des États-Unis." In CoulANGEON Philippe \& Duval Julien (eds.), Trente ans après La Distinction de Pierre Bourdieu. Paris, La Découverte: 59-68.

LeVI Giovanni (1988). Inheriting Power: The Story of an Exorcist. English translation by Lydia G. Cochrane. Chicago, University of Chicago Press. 
LINHART Robert (1981). L'Établi. Paris, Minuit.

MACKENZIE Caroline (2012). « Agency, un mot, un engagement ». Rives méditerranéennes, 41(1). [En ligne] http://rives.revues.org/4139 [consulté le 11 mars 2017].

MatHieu Nicole-Claude (1991). L'Anatomie politique. Paris, Côté-Femmes.

MAUGER Gérard (1991). "Enquêter en milieu populaire ». Genèses, 6 : 125-143.

MAUger Gérard (2005). « Un apprentissage tardif du métier de sociologue ». In MAUGER Gérard (dir.), Rencontres avec Pierre Bourdieu. Bellecombe-en-Bauges, Le Croquant : 239-257.

MAUGeR Gérard (2006a). "Sur la violence symbolique ». In MülleR HansPeter \& Sintomer Yves (dir.). Pierre Bourdieu, théorie et pratique. Paris, La Découverte : 84-100.

MAUGER Gérard (2006b). Les Bandes, le milieu et la bohème populaire. Études de sociologie de la déviance des jeunes des classes populaires (1975-2005). Paris, Belin.

MAUgeR Gérard (2013). " Bourdieu et les classes populaires. L'ambivalence des cultures dominées ». In CoULANGEON Philippe \& DUVAL Julien (dir.), Trente ans après La Distinction de Pierre Bourdieu. Paris, La Découverte : 243-254.

MAUGeR Gérard (2014). « Domination ». Le Lexique socius. [En ligne] http:// ressources-socius.info/index.php/lexique/21-lexique/154-domination [consulté le 14 janvier 2017].

MAUGER Gérard \& FossÉ Claude (1977). La Vie buissonnière. Marginalité petite-bourgeoise et marginalité populaire. Paris, Maspero.
LINHART Robert (1981). The Assembly Line. English Translation by Margaret Crosland. Amherst, University of Massachusetts Press.

MACKENZIE Caroline (2012). "Agency, un mot, un engagement." Rives méditerranéennes, 41(1). [On line] http://rives.revues.org/4139 [accessed on 11 march 2017].

MatHIEU Nicole-Claude (1991). L'Anatomie politique. Paris, Côté-Femmes.

MAUger Gérard (1991). "Enquêter en milieu populaire." Genèses, 6: 125143.

MAUGeR Gérard (2005). "Un apprentissage tardif du métier de sociologue." In MAUGER Gérard (ed.), Rencontres avec Pierre Bourdieu. Bellecombeen-Bauges, Le Croquant: 239-257.

MaUger Gérard (2006a). "Sur la violence symbolique." In Müller HansPeter \& Sintomer Yves (eds), Pierre Bourdieu, théorie et pratique. Paris, La Découverte: 84-100.

MAUger Gérard (2006b). Les Bandes, le milieu et la bohème populaire. Études de sociologie de la déviance des jeunes des classes populaires (1975-2005). Paris, Belin.

MAUGER Gérard (2013). "Bourdieu et les classes populaires. L'ambivalence des cultures dominées." In Coulangeon Philippe \& Duval Julien (eds.), Trente ans après La Distinction de Pierre Bourdieu. Paris, La Découverte: 243-254.

MAUGER Gérard (2014). "Domination." Le Lexique socius. [On line] http:// ressources-socius.info/index.php/lexique/21-lexique/154-domination [accessed on 14 january 2017].

MAUger Gérard \& Fossé Claude (1977). La Vie buissonnière. Marginalité petite-bourgeoise et marginalité populaire. Paris, Maspero. 
MAUGER Gérard \& FossÉ-Poliak Claude (1985). « Choix politiques et choix de recherches. Essai d'auto-socio-analyse (1973-1984) ». Cahiers « Jeunesses et Sociétés », 3-4-5: 27-121.

Menger Pierre-Michel (2009). Le Travail créateur. S'accomplir dans l'incertain. Paris, Gallimard/Seuil, « Hautes études ».

MorRIson Toni (1990). Playing in the Dark : Whiteness and The Literary Imagination. New York, Vintage Books.

Moulin Raymonde (1971). « La Culture du pauvre. À propos du livre de Richard Hoggart ». Revue française de sociologie, 12(2) : 255-258.

Moulin Raymonde (1992). L'Artiste, l'institution et le marché. Paris, Flammarion.

Moulin Raymonde (dir.) (1986). Sociologie del'art. Paris, La Documentation française.

Moulin Raymonde, PASSERON Jean-Claude, PASquIER Dominique, PortoVASQUEZ Fernando (1985). Les Artistes, essai de morphologie sociale. Paris, La Documentation Française.

Naudier Delphine \& Rollet Brigitte (2007). Genre et légitimité culturelle. Quelle reconnaissance pour les femmes ?. Paris, L'Harmattan.

NAVEL Georges (1945). Travaux. Paris, Gallimard.

Neveu Érik (1999). « Pour en finir avec l'enfantisme. Retours sur enquêtes ». Réseaux, 92-93:175-201.
MAUGER Gérard \& FoSSÉ-POLIAK Claude (1985). "Choix politiques et choix de recherches. Essai d'auto-socio-analyse (1973-1984)." Cahiers "Jeunesses et Sociétés", 3-4-5: 27-121.

Menger Pierre-Michel (2014). The Economics of Creativity: Art and Achievement Under Uncertaint. English Translation by Steven Rendall, Amy Jacobs, Arianne Dorval, Lisette Eskinazi, Emmanuelle Saada, Joe Karaganis. Cambridge (Mass.), Harvard University Press.

Morrison Toni (1990). Playing in the Dark: Whiteness and The Literary Imagination. New York, Vintage Books.

Moulin Raymonde (1971). "La Culture du pauvre. À propos du livre de Richard Hoggart." Revue française de sociologie, 12(2): 255-258.

Moulin Raymonde (1992). L'Artiste, l'institution et le marché. Paris, Flammarion.

Moulin Raymonde (ed.) (1986). Sociologie de l'art. Paris, La Documentation française.

Moulin Raymonde, PASSERon Jean-Claude, PAsquier Dominique, PortoVASQUEZ Fernando (1985). Les Artistes, essai de morphologie sociale. Paris, La Documentation Française.

NAUDIER Delphine \& ROLLet Brigitte (2007). Genre et légitimité culturelle. Quelle reconnaissance pour les femmes?. Paris, L'Harmattan.

NAVEL George (1949). Man At Work. English translation by George Reavey. London, Dennis Dobson.

Neveu Érik (1999). "Pour en finir avec l'enfantisme. Retours sur enquêtes." Réseaux, 92-93: 175-201. 
NeVEu Érik (2008). « Les voyages des cultural studies ». L'Homme, 187$188: 315-341$

NoIRIEL Gérard (1988). Le Creuset français. Histoire de l'immigration $\left(X I X^{e}-X X^{e}\right.$ siècle). Paris, Seuil.

OlivieR dE SARDAN Jean-Pierre (2008). La Rigueur du qualitatif. Les contraintes empiriques de l'interprétation socio-anthropologique. Louvain, Bruylant Academia.

Pareto Vilfredo (1917). Traité de sociologie générale. Traduit de l'italien par Pierre Boven. Lausanne, Payot.

Pasquali Paul \& Schwartz Olivier (2016). « La Culture du pauvre : un classique revisité. Hoggart, Les classes populaires et la mobilité sociale ". Politix, 114 : 21-45.

Pasqual Paul (2014). Passer les frontières sociales. Comment les « filières d'élite » entrouvrent leurs portes. Paris, Fayard.

PASqUIER Dominique (1989). La Culture des sentiments. L'expérience télévisuelle des adolescents. Paris, Éditions de la MSH.

PASquier Dominique (2005). "La "culture populaire" à l'épreuve des débats sociologiques ». Hermès, 42 : 60-69.

PASSERON Jean-Claude (2006) [1991]. Le Raisonnement sociologique. Un espace non poppérien de l'argumentation. Paris, Albin Michel, nouvelle édition revue et augmentée (première édition Paris, Nathan).

Passeron Jean-Claude \& Pedler Emmanuel (1991). Le Temps donné aux tableaux. Compte rendu d'une enquête au musée Granet. Marseille, Imerec.
NeVEU Érik (2008). "Les voyages des cultural studies." L'Homme, 187188: $315-341$

NoIRIEL Gerard (1996). The French Melting Pot: Immigration, Citizenship, and National Identity. English Translation by Geoffroy de Laforcade. Minneapolis, University of Minnesota Press.

Olivier de SARDAN Jean-Pierre (2008). La Rigueur du qualitatif. Les contraintes empiriques de l'interprétation socio-anthropologique. Louvain, Bruylant Academia.

PARETO Vilfredo (1935) [1917]. The Mind and Society: A Treatise on General Sociology. English translation by Andrew Bongiorno and Arthur Livingston. New York, Harcourt, Brace and Company.

Pasqual Paul \& Schwartz Olivier (2016). "La Culture du pauvre: un classique revisité. Hoggart, Les classes populaires et la mobilité sociale." Politix, 114: 21-45.

Pasquali Paul (2014). Passer les frontières sociales. Comment les "filières d'élite" entrouvrent leurs portes. Paris, Fayard.

PASquIER Dominique (1989). La Culture des sentiments. L'expérience télévisuelle des adolescents. Paris, Éditions de la MSH.

PASQUIER Dominique (2005). "La 'culture populaire' à l'épreuve des débats sociologiques." Hermès, 42: 60-69.

PASSERON Jean-Claude (2013). Sociological Reasoning. A Non-Popperian Space of Argumentatio. English Translation by Rachel Gomme, Edited and Introduced by Professor Derek Robbins. Oxford, Bardwell Press.

Passeron Jean-Claude \& Pedler Emmanuel (1991). Le Temps donné aux tableaux. Compte rendu d'une enquête au musée Granet. Marseille, Imerec. 
PASSERON Jean-Claude \& Grumbach Michel (dir.) (1985). L'CEil à la page enquête sur les images et les bibliothèques. Paris, Bibliothèque publique d'information, Service des études et de la recherche.

PASSERON Jean-Claude (dir.) (1999). Richard Hoggart en France. Paris, Bibliothèque publique d'information.

PedLer Emmanuel (2010). « Les sociologies de la musique de Max Weber et Georg Simmel. Une théorie relationnelle des pratiques musiciennes ». L'Année sociologique, 60(2) : 305-330.

Pedler Emmanuel (2016). L'Esprit des lieux. Paris, Éditions de l'EHESS.

Pedler Emmanuel \& Bourbonnaud David (2002a). « L'offre du festival "in" d'Avignon : effet d'imposition ou stimulation culturelle ? ». Actes du colloque d'Amiens.

Pedler Emmanuel \& Bourbonnaud David (2002b). « La programmation du Festival. Un pacte de confiance entre l'organisation festivalière et son public ». In ETHIS Emmanuel (dir.), Avignon : le public réinventé. Paris, La Documentation française : 131-159.

Pedler Emmanuel \& ZerbiB Olivier (2001). Les Nouvelles Technologies à l'épreuve des bibliothèques. Paris, Bibliothèque publique d'information.

Peterson Richard A. \& Simkus Albert (1992). « How Musical Tastes Mark Occupational Status Groups ». In LAMONT Michèle \& FOURNIER Marcel, Cultivating differences : Symbolic Boundaries and the Making of Inequality. Chicago, The University of Chicago Press : 152-168.

Peterson Richard A. (1992). « Understanding audience segmentation : From elite and mass to omnivore and univore ». Poetics, 21(4) : 243-258.

Peterson Richard A. (1997). « The Rise and Fall of Highbrow Snobbery as a Status Marker ». Poetics, 25(2-3) : 75-92.
PASSERON Jean-Claude \& GRUMBACH Michel (eds.) (1985). L'CEil à la page. enquête sur les images et les bibliothèques. Paris, Bibliothèque publique d'information, Service des études et de la recherche.

PASSERON Jean-Claude (ed.) (1999). Richard Hoggart en France. Paris, Bibliothèque publique d'information.

Pedler Emmanuel (2010). "Les sociologies de la musique de Max Weber et Georg Simmel. Une théorie relationnelle des pratiques musiciennes." L'Année sociologique, 60(2): 305-330.

Pedler Emmanuel (2016). L'Esprit des lieux. Paris, Éditions de l'EHESS.

Pedler Emmanuel \& Bourbonnaud David (2002a). "L'offre du festival 'in' d'Avignon: effet d'imposition ou stimulation culturelle?." Actes du colloque d'Amiens.

Pedler Emmanuel \& Bourbonnaud David (2002b). "La programmation du Festival. Un pacte de confiance entre l'organisation festivalière et son public." In ETHIS Emmanuel (ed.), Avignon: le public réinventé. Paris, La Documentation française: 131-159.

Pedler Emmanuel \& ZerbiB Olivier (2001). Les Nouvelles Technologies à l'épreuve des bibliothèques. Paris, Bibliothèque publique d'information.

Peterson Richard A. \& Simkus Albert (1992). "How Musical Tastes Mark Occupational Status Groups." In LAMONT Michèle \& FouRNIER Marcel, Cultivating differences: Symbolic Boundaries and the Making of Inequality. Chicago, The University of Chicago Press: 152-168.

Peterson Richard A. (1992). "Understanding audience segmentation: From elite and mass to omnivore and univore." Poetics, 21(4): 243-258.

Peterson Richard A. (1997). "The Rise and Fall of Highbrow Snobbery as a Status Marker." Poetics, 25(2-3): 75-92. 
Peterson Richard A. \& Kern Roger M. (1996). "Changing Highbrow Taste : from Snob to Omnivore ». American Sociological Review, 61(5) : 900-907.

PUDAL Bernard (1991). « Le populaire à l'encan ». Politix, $13:$ 53-64.

RANCIÈRE Jacques (1981). La Nuit des prolétaires. Archives du rêve ouvrier. Paris, Fayard.

Ranclère Jacques (2011). La Leçon d'Althusser. Paris, La Fabrique.

Revel Jacques (dir.) (1996). Jeux d'échelles. La micro-analyse à l'expérience. Paris, Gallimard/Seuil.

Robinson Eric E. (1968). The New Polytechnics. The People's Universities. Harmondsworth, Penguin.

RoEDiger David (1991). The Wages of Whiteness : Race and the Making of the American Working Class. New York, Verso.

SAPIRO Gisèle (2013a). « La carrière internationale de La Distinction ». In CoULANGEON Philippe \& DuvaL Julien (dir.), Trente ans après La Distinction de Pierre Bourdieu. Paris, La Découverte : 45-58.

SAPIRO Gisèle (2013b). « Le champ est-il national ? La théorie de la différenciation sociale au prisme de l'histoire globale ". Actes de la recherche en sciences sociales, $200: 70-85$

SCHILLING Heinz (1981). Konfessionskonflikt und Staatsbildung. Eine Fallstudie über das Verhältnis von religiösem und sozialem Wandel in der Früh Neuzeit am Beispiel der Grafschaft Lippe. Gütersloh, Bertelsmann.
Peterson Richard A. \& Kern Roger M. (1996). "Changing Highbrow Taste: from Snob to Omnivore." American Sociological Review, 61(5): 900-907.

PUDAL Bernard (1991). "Le populaire à l'encan." Politix, 13: 53-64.

RANCIĖRE Jacques (1989). The Nights of Labor : the Workers' Dream in Nineteenth-Century France. English Translation by John Drury. Philadelphia, Temple University.

Rancière Jacques (2011). Althusser's Lesson. English Translation by Emiliano Battista. London, Bloomsbury Publishing.

ReVEL Jacques (ed.) (1996). Jeux d'échelles. La micro-analyse à l'expérience. Paris, Gallimard/Seuil.

Robinson Eric E. (1968). The New Polytechnics. The People's Universities. Harmondsworth, Penguin.

Roediger David (1991). The Wages of Whiteness: Race and the Making of the American Working Class. New York, Verso.

SAPIRO Gisèle (2013a). "La carrière internationale de La Distinction". In Coulangeon Philippe \& Duval Julien (eds.). Trente ans après La Distinction de Pierre Bourdieu. Paris, La Découverte: 45-58.

SAPIRO Gisèle (2013b). "Le champ est-il national? La théorie de la différenciation sociale au prisme de l'histoire globale." Actes de la recherche en sciences sociales, 200: 70-85.

SCHILLING Heinz (1981). Konfessionskonflikt und Staatsbildung. Eine Fallstudie über das Verhältnis von religiösem und sozialem Wandel in der Früh Neuzeit am Beispiel der Grafschaft Lippe. Gütersloh, Bertelsmann. 
ScotT James (2008). La Domination et les arts de la résistance. Fragments du discours subalterne. Traduction française par Olivier Ruchet. Paris, Éditions Amsterdam.

Servien Pius (1935). Principes d'esthétique. Problèmes d'art et langage des sciences. Paris, Boivin.

SINGLY François (DE) (1998). « Bourdieu : nom propre d'une entreprise collective ». Le Magazine littéraire, 369 : 39-44.

SUTton-SMith Brian (1970). «Psychology of Childlore : The Triviality Barrier ». Western Folklore, 29(1) : 1-8.

TAINE Hyppolite (1858). Essais de critique et d'histoire. Paris, Hachette. VeYNe Paul (1971). Comment on écrit l'histoire. Essai d'épistémologie. Paris, Seuil.

VeYNE Paul (2008). Foucault. Sa pensée, sa personne. Paris, Albin Michel.

WeBer Max (1998) [1921]. Sociologie de la musique. Les fondements rationnels et sociaux de la musique [Die rationalen und soziologischen Grundlagen der Musik, Tübingen, Drei Masken Verlag]. Traduit de l'allemand par Jean Molino et Emmanuel Pedler. Paris, Métailié.

Wimmer Andreas \& Glick Schiller Nina (2002). " Methodological Nationalism and Beyond : Nation-State Building, Migration and the Social Sciences ». Global Network, 2 : 301-334.
ScotT James (1992). Domination and the Arts of Resistance: Hidden Transcripts. Yale, Yale University Press.

Servien Pius (1935). Principes d'esthétique. Problèmes d'art et langage des sciences. Paris, Boivin.

SINGLY François (DE) (1998). "Bourdieu: nom propre d'une entreprise collective." Le Magazine littéraire, 369: 39-44.

SUTTON-SMith Brian (1970). "Psychology of Childlore: The Triviality Barrier." Western Folklore, 29(1): 1-8.

TAINE Hyppolite (1858). Essais de critique et d'histoire. Paris, Hachette. VEYNE Paul (1971). Comment on écrit l'histoire. Essai d'épistémologie. Paris, Seuil.

VeYNE Paul (2010). Foucault: His Thought, His Character. English Translation by Janet Lloyd. Cambridge, Polity Press.

Weber Max (1958) [1921]. The Rational And Social Foundations Of Music. English Translation by Don Martindale, Johannes Riedel, Gertrude Neuwirth. Carbondale, Southern Illionios University Press.

Wimmer Andreas \& Glick Schiller Nina (2002). "Methodological Nationalism and Beyond: Nation-State Building, Migration and the Social Sciences." Global Network, 2: 301-334. 